Jurnal Keperawatan Silampari

Volume 4, Nomor 2, Juni 2021

e-ISSN: 2581-1975

p-ISSN: 2597-7482

DOI: https://doi.org/10.31539/jks.v4i2.1946

IDMEKRE

\title{
STRES KERJA DENGAN PERILAKU CARING PETUGAS KESEHATAN DALAM PENANGANAN PASIEN PADA MASA PANDEMI COVID-19
}

\author{
Lisnawati Yupartini ${ }^{1}$, Epi Rustiawati ${ }^{2}$, Tuti Sulastri ${ }^{3}$ \\ Universitas Sultan Ageng Tirtayasa ${ }^{1,2,3}$ \\ ylisnawati37@gmail.com ${ }^{1}$
}

\begin{abstract}
ABSTRAK
Penelitian ini bertujuan untuk mengetahui hubungan stres kerja tenaga kesehatan dengan perilaku caring di Puskesmas Kota Serang. Jenis penelitian ini adalah survey analitik dengan desain cross-sectional. Hasil penelitian didapatkan 43,2\% tenaga kesehatan dengan stres sedang dan 29,1\% tenaga kesehatan kurang caring. Hasil analisis bivariat menunjukkan bahwa nilai $(\mathrm{p}=0.00)$. Simpulan, terdapat hubungan antara stres kerja tenaga kesehatan dengan perilaku caring di Puskesmas di Kota Serang Tahun 2020
\end{abstract}

Kata Kunci: Caring, Pandemi Covid-19, Stres Kerja, Tenaga Kesehatan

\begin{abstract}
This study aims to determine the relationship between work stres of health workers and caring behavior at the Serang City Health Center. This type of research is an analytic survey with a cross-sectional design. The results showed that $43.2 \%$ of health workers with moderate stres and $29.1 \%$ of health workers lacked caring. The results of the bivariate analysis showed that the value $(p=0.00)$. In conclusion, there is a relationship between the work stres of health workers and caring behavior at the Puskesmas in Serang City in 2020
\end{abstract}

Keywords: Caring, Covid-19 Pandemic, Work Stres, Health Workers

\section{PENDAHULUAN}

Covid-19 merupakan virus jenis baru yang ditemukan pada tahun 2019 dan belum pernah ditemukan menyerang manusia sebelumnya (WHO, 2020; Zulva, 2019). Covid-19 adalah penyakit menular yang disebabkan oleh Sindrom Pernafasan Akut Coronavirus 2 (Severe Acute Respiratory Syndrome Coronavirus 2 atau SARS-CoV02) (Setiawan, 2020). WHO menyatakan virus corona sebagai pandemi pada 11 Maret 2020, dan virus ini menyebar dengan sangat cepat (Moana, 2020). Status pandemi atau epidemi global menunjukkan bahwa penyebaran Covid-19 sangat cepat.

Kondisi saat ini membuat masyarakat tidak siap secara fisik dan psikologis untuk merespons (Sabir \& Phil, 2016). Wang et al., (2020) Dijelaskan pula bahwa dampak pandemi Covid-19 telah menimbulkan banyak kerugian seperti hambatan fisik, ketimpangan ekonomi, ketimpangan sosial dan gangguan jiwa. Saat terinfeksi virus corona ini, kondisi psikologis yang dialami masyarakat akan merasa cemas (Fitria et al., 2020). Huang et al., (2020) menjelaskan, gangguan jiwa yang terjadi selama pandemi Covid-19 adalah kecemasan, ketakutan, stres, depresi, panik, sedih, depresi, marah, dan penyangkalan. 
Stres kerja dapat mempengaruhi kualitas hidup tenaga kesehatan yang secara bersamaam mengurangi kualitas caring pelayanan kesehatan, caring adalah prosedur interpersonal, kepekaan interpersonal termasuk komunikasi positif dan implemetasi pengetahuan dan keterampilan professional. Stres terkait pekerjaan akan mengakibatkan hilangnya caring dan meningkatkan insiden keslahan praktik. Keadaan ini adalah hal yang paling merugikan dalam pelayanan kesehatan (Health and Safety Executive, 2017).

Sejak akhir Desember 2019, kota Wuhan di Cina telah melaporkan adanya pneumonia baru yang disebabkan oleh penyakit coronavirus 2019 (COVID-19), yang telah menyebar secara Internasional. Data di Indonesia menunjukkan 4.839 orang menunjukkan terkonfimasi positif COVID-19, dengan kematian 9,48\% (Tosepu et al., 2020). Menghadapi situasi kritis ini, petugas kesehatan di garis depan yang terlibat langsung dalam diagnosis, pengobatan, dan perawatan pasien COVID-19 berisiko berkembang secara psikologis kesusahan dan gejala fisiologis lainnya. Petugas kesehatan menghadapi beban kerja yang berat, peralatan perlindungan yang menipis, perasaan tidak didukung yang berkontribusi pada keadaan stres. Masa pandemi Covid 19 mengubah tata cara dan jam pelayanan di puskesmas, keadaan ini dapat menimbulkan stres kerja dapat dapat mengakibatkan rendahnya perilaku caring yang diberikan petugas kesehatan kepada pasien. dan tidak terbiasanya dengan pemakain alat pelindung diri yang menutupi rapat anggota tubuh petugas yang membuat rasa tidak nyaman selama bekerja.

Studi sebelumnya pada petugas kesehatan menunjukkan reaksi psikologis yang tidak normal pada saat menghadapi wabah SARS 2003 diantaranya petugas kesehatan takut akan penularan dan infeksi pada keluarga, teman, dan tetangga. Psikologis yang dirasakan petugas kesehatan merasa stigmatisasi dan ketidakpastian, keengganan untuk bekerja, mengalami stres tingkat tinggi, kecemasan dan gejala depresi (Health and Safety Executive, 2017).

Hasil studi pendahuluan di Puskesmas Kota Serang dalam 3 bulan terakhir yaitu Februari, Maret, dan April 2020 angka kunjungan pasien rata-rata 480 s.d. 600 orang. Jumlah tenaga kesehatan 128 orang. Hasil wawancara dengan 10 orang petugas kesehatan, 3 orang bidan mengeluhkan lelah dan badan terasa pegal setelah pulang bertugas, 4 orang mengatakan leher terasa tegang selama kerja, 2 orang mengatakan terasa malas masuk kerja. Berdasarkan hasil observasi terhadap pasien, pasien mengatakan petugas melayani pasien sesuai dengan kebutuhan, namun petugas tidak menjelaskan informasi berbeda saat masa sebelum pandemi. Selama ini pihak manajemen puskesmas telah melakukan upaya peningkatan pelayanan kesehatan termasuk perilaku caring melalui kegiatan pertemuan rutin bulanan yang dipimpin oleh kepala puskesmas.

\section{METODE PENELITIAN}

Jenis penelitian ini analitik dengan pendekatan secara potong lintang (cross sectional). Penelitian ini dilaksanakan dari bulan Mei - November 2020. Populasi dalam penelitian ini adalah tenaga kesehatan di Puskesmas di Kota Serang. Jumlah sampel dalam penelitian ini adalah 148 orang.

Pengumpulan data dilakukan pada tenaga kesehatan di puskesmas si Kota Serang. Teknik pengumpulan data yang digunakan dalam penelitian ini adalah menggunakan instrumen berupa kuesioner stres kerja dan caring.

Pengolahan data dalam penelitian ini menggunakan program SPSS. Analisis univariat gambaran distribusi frekuensi stres kerja dan caring. Analisis bivariat dilakukan dengan uji chi square antara variabel stres kerja dan caring. 
HASIL PENELITIAN

Gambaran Stres Kerja Tenaga Kesehatan

Tabel. 1

Distribusi Frekuensi Stres Kerja

Tenaga Kesehatan $(n=148)$

\begin{tabular}{lcc}
\hline \multicolumn{1}{c}{ Stres Kerja Tenaga Kesehatan } & Frekuensi & Presentase (\%) \\
\hline Sedang & 64 & 43,2 \\
Ringan & 84 & 56,8 \\
\hline Total & 148 & 100,0 \\
\hline
\end{tabular}

Berdasarkan tabel 1 dapat dijelaskan bahwa hasil analisis distribusi frekuensi stres kerja pada 148 responden yang diteliti diketahui sebagian besar responden mengalami stres kerja ringan yaitu sebanyak $84(56,8 \%)$ responden.

\section{Gambaran Perilaku Caring}

Tabel. 2

Distribusi Frekuensi Stres Kerja Tenaga Kesehatan di Puskesmas Kota Serang ( $\mathrm{n}=148)$

\begin{tabular}{lcl}
\hline \multicolumn{1}{c}{ Perilaku Caring } & Frekuensi & Presentase (\%) \\
\hline Kurang Caring & 43 & 29,1 \\
Caring & 105 & 70,9 \\
\hline Total & 148 & 100,0 \\
\hline
\end{tabular}

Berdasarkan tabel 2 menunjukkan hasil analisis distribusi frekuensi perilaku caring pada tenaga kesehatan ruang penyakit dalam tampak bahwa dari total 148 responden yang diteliti diketahui sebagian besar responden mempunyai perilaku caring yaitu sebanyak 105 $(70,9 \%)$ responden.

\section{Hubungan Stres Kerja Tenaga Kesehatan dengan Perilaku Caring}

Tabel. 3

Hubungan Stres Kerja Tenaga Kesehatan dengan Perilaku Caring $(\mathrm{n}=148)$

\begin{tabular}{|c|c|c|c|c|c|c|c|c|}
\hline \multirow{3}{*}{$\begin{array}{l}\text { Stres Kerja Tenaga } \\
\text { kesehatan }\end{array}$} & \multicolumn{4}{|c|}{ Perilaku Caring } & \multirow{2}{*}{\multicolumn{2}{|c|}{ Total }} & \multirow[b]{2}{*}{ Nilai p } & \multirow{2}{*}{$\begin{array}{c}\text { OR } \\
(95 \% \\
\text { CI) }\end{array}$} \\
\hline & \multicolumn{2}{|c|}{$\begin{array}{l}\text { Kurang } \\
\text { Caring } \\
\end{array}$} & \multicolumn{2}{|c|}{ Caring } & & & & \\
\hline & $\mathrm{n}$ & $\%$ & $\mathrm{n}$ & $\%$ & $\mathrm{n}$ & $\%$ & 0,00 & 6,636 \\
\hline Sedang & 32 & 50 & 32 & 50 & 64 & 100 & & $(2,978-$ \\
\hline Ringan & 11 & 13,1 & 73 & 86,9 & 84 & 100 & & $14,78)$ \\
\hline Jumlah & 43 & 29,1 & 105 & 70,9 & 148 & 100,0 & & \\
\hline
\end{tabular}

Berdasarkan tabel 3 menunjukkan bahwa dari 64 tenaga kesehatan dengan stres kerja sedang sebagian $32(50 \%)$ mempunyai perilaku caring. Jika dibandingkan dengan tenaga kesehatan dengan stres kerja ringan sebagian besar yang mempunyai perilaku caring yaitu $73(86,9 \%)$ dari 84 tenaga kesehatan di puskesmas. Hal ini menunjukkan semakin stres akan menjadi berperilaku kurang caring. 


\section{PEMBAHASAN}

\section{Gambaran Stres Kerja Tenaga kesehatan}

Berdasarkan tabel 1 dapat dijelaskan bahwa hasil analisis distribusi frekuensi stres kerja pada 148 responden yang diteliti diketahui sebagian besar responden mengalami stres kerja ringan. Stres harian, dibanding dengan peristiwa trumatis merupakan faktor prediktor yang dapat mempengaruhi kesehatan mental lebih besar. Respon stres fisiologis yang berkepanjangan merupakan faktor risiko yang dapat menimbulkan suatu penyakit (Schönfeld et al., 2016). Keadaan pandemi Covid-19 yang telah berlangsung selama berbulan-bulan dapat dijadikan sebagai stresor yang berkepanjangan. Respon stres berkepanjangan sebagian besar tidak disadari atau dianggap sebagai penyebab stres (Krystal \& McNeil, 2020; Lin et al., 2020).

Stres kerja tenaga kesehatan secara biologis yang dialami responden yaitu sebagian besar merasa otot kaku setelah bekerja, tangan terasa capek, betis terasa pegal, persendian terasa ngilu, nyeri punggung, nyeri pinggang, dan makan secara berlebihan. Stres kerja selama masa pandemi Covid-19 secara psikologis yang sebagian besar dialami responden yaitu merasa tertekan karena bekerja dalam situasi menegangkan, merasa tidak aman untuk menyelesaikan pekerjaan, merasa ketakutan tertular Covid-19 dalam bekerja, dan merasa tidak puas terhadap pekerjaan (Brosschot et al., 2018). Selanjutnya sebagian besar tenaga kesehatan mengalami stres kerja secara sosial terdiri dari mudah tersinggung, ketegangan dalam berinteraksi dengan teman sejawat, mengalami mimpi buruk, mengalami insomnia, kecemasan dan mudah marah tanpa sebab yang berarti apabila tidak diatasi gejala ini dapat menyebakan gangguan fungsional tenaga kesehatan termasuk gangguan mood dan kecemasan (Health and Safety Executive, 2017).

Hal ini sejalan dengan keadaan tenaga kesehatan saat menghadapi penyakit ebola (Krystal \& McNeil, 2020). Stresor yang sama terhadap petugas kesehatan dapat dipersepsikan secara berbeda, yaitu dapat sebagai peristiwa yang positif yang tidak berbahaya, atau menjadi peristiwa yang berbahaya dan mengancam (Schönfeld et al., 2016). Beberapa penelitian tentang stres kerja terhadap tenaga kesehatan juga telah dilakukan berhubungan dengan beban kerja berlebih (work overload), tuntutan waktu pengerjaan tugas yang cepat, tidak adanya dukungan sosial dalam bekerja (khususnya dari supervisor, kepala tenaga kesehatan dan managerial ketenaga kesehatanan yang lebih tinggi), terpapar penyakit infeksi, tertusuk jarum, dan berhubungan dengan pasien sulit atau kondisi sulit pasien yang serius.

\section{Gambaran Perilaku Caring}

Berdasarkan tabel 2 menunjukkan hasil analisis distribusi frekuensi perilaku caring pada tenaga kesehatan ruang penyakit dalam diketahui bahwa sebagian besar responden mempunyai perilaku caring. Caring merupakan rasa kepedulian, penuh dengan rasa hormat, penuh kasih dan professional dalam melaksanakan pelayanan kesehatan dimasamasa sulit pandemi Covid-19. Caring dikatakan juga sebagai sikap altruistik untuk bertindak dan merasa empati terhadap sesama manusia. Dari tabel 2 menunjukkan masih ada petugas kehatan yang bersikap kurang melaksanakan perilaku caring, hal ini dikarenakan tenaga kesehatan terdapak oleh adanya stresor oleh karena keadaan pandemi Covid-19.

Petugas kesehatan menampilkan caring bertujuanmeningkatkan rasa aman dan keselamatan pasien saat pemberian pelayanan kesehatan. Kemudian caring juga menekankan harga diri individu, artinya dalam melakukan praktik ketenaga kesehatanan, tenaga kesehatan senantiasa selalu menghargai klien dengan menerima kelebihan maupun 
kekurangan klien sehingga bisa memberikan pelayanan kesehatan yang tepat (Olender, 2017).

\section{Hubungan Stres Kerja Tenaga Kesehatan dengan Perilaku Caring}

Penyakit Covid-19 telah menyebabkan kekhawatiran setiap orang akan tertular penyakit tersebut, termasuk para petugas kesehatan yang berada di garis terdepan menghadapi virus corona ini. Keadaan stres pada petugas kesehatan ditampilkan melalui tingkat depresi, kecemasan, dan insomnia. Keadaan stres akan mempengaruhi hasil kerja tenaga kesehatan. Pada masa pandemi Covid-19 ini tantangan dan kesulitan dalam bekerja menjadi meningkat, petugas kesehatan diwajibkan memberikan pelayanan kesehatan yang optimal dengan keadaan situasi pandemi Covid-19. Mekanisme koping petugas kesehatan dalam adaptasi pada masa pandemi Covid-19 akan menentukan perilaku caring yang ditampilkan (Krystal \& McNeil, 2020).

Hasil tersebut menunjukkan bahwa sres kerja tenaga kesehatan sangat mempengaruhi perilaku caring pada tenaga kesehatan di puskesmas, hal ini dibuktikan dengan hasil uji statistik dengan tingkat kepercayaan 95\% diperoleh nilai $p$ sebesar $0,000(p<\alpha)$ yang berarti $\mathrm{H}_{0}$ ditolak artinya terdapat hubungan yang bermakna antara stres kerja tenaga kesehatan dengan perilaku caring. Lingkungan bekerja pada masa pandemi Covid-19 berpotensi sebagai stresor kerja. Distres yang muncul merupakan adanya gangguan fungsional organ yang akan berpengaruh terhadap seseorang yang tidak mampu memberikan pelayanan kesehatan optimal, termasuk menampilkan perilaku caring (Olender, 2017).

Masa pandemi Corona Virus Disease (Covid-19) membawa dampak perubahan dunia. Mulai aspek ekonomi, social, tidak terkecuali terhadap pelayanan kesehatan, mulai dari sarana pelayanan kesehatan tingkat pertama yaitu pusksmas sampai dengan tingka lanjut yaitu rumah sakit. Petugas kesehatan sebagai garda terdepan dihadapkan dengan musuh yang tak kasat mata dan tidak bisa terdeteksi keberadaanya sehingga diharuskan patuh terhadap kebijakan pemerintah yaitu wajib memakai baju pelindung diri (hazmat suit) dan pelindung wajah (face shield). Masyarkat yang akan berobat ke puskesmas diarahkan menuggu di luar gedung dengan pemberlakuan physical distancing. Jam pelayanan puskesmas ditambah bagi puskesmas yang tidak melayani pasien rawat inap.

Olender menambahkan bahwa caring yang dilakukan dengan efektif dapat mendorong kesehatan dan pertumbuhan individu, terdapat adanya hubungan yang signifikan antara persepsi mengenai perilaku caring tenaga kesehatan dengan kepuasan pasien terhadap pelayanan ketenaga kesehatanan (Olender, 2017). Pelayanan kesehatan pada masa pandemi Covid-19 merupakan suatu tantangan besar bagi petugas kesehatan, dimana petugas harus menampilkan perilaku caring dalam pemberian pelayanan kesehatan ditengah adanya stres yang dialami oleh petugas kesehatan itu sendiri. Perilaku caring tenaga kesehatan tidak hanya mampu meningkatkan kepuasan klien, namun juga dapat menghasilkan keuntungan bagi puskesmas menyampaikan bahwa perilaku caring dapat mendatangkan manfaat finansial bagi industri pelayanan kesehatan. Perilaku caring staf kesehatan mempunyai nilai ekonomi bagi puskesmas karena perilaku ini berdampak bagi kepuasan pasien. Dengan demikian, secara jelas dapat diketahui bahwa perilaku caring tenaga kesehatan dapat memberikan kemanfaatan bagi pelayanan kesehatan karena dapat meningkatkan kesehatan dan pertumbuhan individu serta meningkatakan kepuasan pasien sehingga akan meningkatkan kunjungan pasien ke puskesmas dan pada akhirnya memberikan keuntungan finansial bagi puskesmas. 


\section{SIMPULAN}

Terdapat hubungan antara stres kerja tenaga kesehatan dengan perilaku caring di Puskesmas di Kota Serang Tahun 2020.

\section{SARAN}

Saran bagi Puskesmas di Kota Serang diharapkan kepada Kepala Puskesmas membuka saluran khusus/ ruang khusus dan konfrensi melalui video sebagai wadah konseling tenaga kesehatan agar dapat mengelola stres secara konstruktif.

\section{DAFTAR PUSTAKA}

Brosschot, J. F., Verkuil, B., \& Thayer, J. F. (2018). Generalized Unsafety Theory of Stres: Unsafe Environments and Conditions, and the Default Stres Response. International Journal of Environmental Research and Public Health, 15(3), 1-27. https://doi.org/10.3390/ijerph15030464

Health and Safety Executive. (2017). Work-related Stres, Depression or Anxiety Statistics in Great Britain 2017. In Health and Safety Executive report. www.hse.gov.uk/statistics/

Fitria, L., Neviyarni, N., \& Karneli, Y. (2020). Cognitive Behavior Therapy Counseling untuk Mengatasi Anxiety dalam Masa Pandemi Covid-19. Al-Irsyad: Jurnal Pendidikan Dan Konseling, 10(1), 23-29. http://jurnal.uinsu.ac.id/index.php/alirsyad/article/viewFile/7651/3538

Huang, C., Wang, Y., Li, X., Ren, L., Zhao, J., Hu, Y., Zhang, L., Fan, G., Xu, J., Gu, X., Cheng, Z., Yu, T., Xia, J., Wei, Y., Wu, W., Xie, X., Yin, W., Li, H., Liu, M., \& Cao, B. (2020). Clinical Features of Patients Infected with 2019 Novel Coronavirus in Wuhan, China. The Lancet, 395(10223), 497-506. https://doi.org/10.1016/S01406736(20)30183-5

Krystal, J. H., \& McNeil, R. L. (2020). Responding to the Hidden Pandemic for Healthcare Workers: Stres. Nature Medicine, 26(5), 639. https://doi.org/10.1038/s41591-0200878-4

Lin, K., Yang, B. X., Luo, D., Liu, Q., Ma, S., Huang, R., \& McIntyre, R. S. (2020). The Mental Health Effects of COVID-19 on Health Care Providers in China. American Journal of Psychiatry, 177(7), 635-636. https://doi.org/10.1176/appi.ajp.2020.20040374

Moana, N. (2020). Konsep Isolasi dalam Jaringan Sosial untuk Meminimalisasi Efek Contagious (Kasus Penyebaran Virus Corona di Indonesia). Jurnal Sosial Humaniora Terapan, 2(2), 117-125. https://doi.org/10.7454/jsht.v2i2.86

Olender, L. (2017). The Relationship Between and Factors Influencing Staff Nurses' Perceptions of Nurse Manager Caring and Exposure to Workplace Bullying in Multiple Healthcare Settings. Journal of Nursing Administration, 47(10), 501-507. https://doi.org/10.1097/NNA.0000000000000522

Sabir, A., \& Phil, M. (2016). Gambaran Umum Persepsi Masyarakat terhadap Bencana di Indonesia. Jurnal Ilmu Ekonomi dan Sosial, 5(3), 304-326. https://media.neliti.com/media/publications/237547-gambaran-umum-persepsimasyarakat-terhad-501404e6.pdf

Schönfeld, P., Brailovskaia, J., Bieda, A., Zhang, X. C., \& Margraf, J. (2016). The Effects of Daily Stres on Positive and Negative Mental Health: Mediation Through SelfEfficacy. International Journal of Clinical and Health Psychology, 16(1), 1-10. https://doi.org/10.1016/j.ijchp.2015.08.005 
Setiawan, A. R. (2020). Lembar Kegiatan Literasi Saintifik untuk Pembelajaran Jarak Jauh Topik Penyakit Coronavirus 2019 (COVID-19). Edukatif: Jurnal Ilmu Pendidikan, 2(1), 28-37. https://doi.org/10.31004/edukatif.v2i1.80

Tosepu, R., Gunawan, J., Effendy, D. S., Lestari, H., Bahar, H., \& Asfian, P. (2020). Correlation between Weather and Covid-19 Pandemic in Jakarta, Indonesia. Science of The Total Environment. DOI: 10.1016/j.scitotenv.2020.138436

Wang, Z., Qiang, W., \& Ke, H. (2020). A Handbook of 2019-nCoV Pneumonia Control and Prevention. In Hubei Science and technology press. http://fpmpam.org/files/Handbook_2019nCoV.pdf

WHO. (2020). Report of the WHO-China Joint Mission on Coronavirus Disease 2019 (COVID-19). The WHO-China Joint Mission on Coronavirus Disease 2019, 2019(February), 16-24. https://www.who.int/docs/default-source/coronaviruse/whochina-joint-mission-on-covid-19-final-report.pdf

Zulva, T. N. I. (2019). Covid-19 dan Kecenderungan Psikosomatis. Journal of Chemical Information and Modeling, 53(9), 1689-1699 